\title{
Microbial and senzory quality of raw milk cheeses from the milk vending machines
}

\author{
Alžbeta Medved’ová, Adriana Studeničová, \\ Lubomír Valík, Ondruš Ladislav \\ Department of Nutrition and Food Assessment, Faculty of Chemical and Food Technology, \\ Slovak University of Technology in Bratislava Radlinského 9, SK-812 37, Bratislava, Slovak Republic \\ alzbeta.medvedova@stuba.sk
}

\begin{abstract}
Changes in microbial quality of lump cheeses manufactured from raw cows' milk from milk vending machines were studied throughout 7 days of fermentation at $15{ }^{\circ} \mathrm{C}$. The density of lactic acid bacteria, Staphylococcus aureus, Escherichia coli and coliforms were determined, continuously. Also the $\mathrm{pH}$ value dynamic was analyzed at the same time intervals. All together, 8 cheeses were prepared from two different vending machines in summer and in winter. Based on the results, growth dynamic of all microorganisms as well as the $\mathrm{pH}$ value decrease was slower in cheeses made in winter. No significant differences were observed in the maximal counts of microorganisms related to the season. However, the counts of $S$. aureus exceeded the EU limit $10^{4} \mathrm{CFU} \mathrm{g} \mathrm{g}^{-1}$ in 7 out of 8 cheeses, probably due to slow $\mathrm{pH}$ value descent. Also the Slovak Food Codex limit for E. coli maximal density of less than $10^{4} \mathrm{CFU} \mathrm{g}^{-1}$ was significantly exceeded. According to sensory evaluation, cheeses prepared in winter were less tasty and their typical odour was less distinctive. Results suggest that raw milk from milk vending machines is not suitable for direct consumption without proper thermal treatment.
\end{abstract}

Keywords: raw milk cheese, microbial safety, sensory analysis

\section{Introduction}

Although cheeses are considered as one of the safest foods, some infrequent outbreaks of food-borne illnesses occurred in the history. The pathogens, Salmonella enterica, Listeria monocytogenes, Staphylococcus aureus and enteropathogenic Escherichia coli, pose the greatest risk to the safety of cheeses (Donnelly, 2004). The most frequent source of cheeses contamination can be the raw, insufficiently pasteurized milk, or post-pasteurized contaminated milk from the raw milk or from the dairy environment (Little et al., 2008).

$S$. aureus is considered as one of the ubiquitous contaminant. Typical counts of $S$. aureus in properly drawn milk are between 100 and $200 \mathrm{CFU} \mathrm{mL}^{-1}$ (Valík et al., 2004). During cheesemaking, it can multiply about 5 log counts (Delbes et al., 2006), to the critical density higher than $10^{6} \mathrm{CFU} \mathrm{mL} \mathrm{mL}^{-1}$ required to assumptive enterotoxins production (Lindqvist et al., 2002). The presence of toxin-producing strains in raw milk is dependent on various factors, including animal health, environmental, hygienic and technological conditions (Valík et al., 2011). The S. aureus growth is inhibited by fermentative metabolism of lactic acid bacteria, especially, during the fermentation and ripening of cheeses. However, once formed the thermostable enterotoxins, they generally retain their biological activity even after killing of cells by pasteurization. Therefore, sufficient acidification, especially in the early stages of cheese-making, must be achieved by the use of an appropriate amount of an active starter culture (Lindqvist et al., 2002; Asperger and Zangerl, 2003; LeMarc et al., 2009).

E. coli, due to the fermentation of residual lactose, causes the early flatulence of cheeses with the lowtemperature heated casein $\left(36\right.$ to $\left.40^{\circ} \mathrm{C}\right)$. By the crosscontamination during cheese-making or during handling with cheeses, the shiga-toxin E. coli can enter to the food chain (Lim et al., 2007; Rivas et al., 2007). However, the pasteurization and the sterilization processes devitalize E. coli, according to Burdová and Lauková (2001), also the active decreasing of the $\mathrm{pH}$ value down to 5.0 can inhibited even eliminated the growth and multiplication of E. coli.

In this connection, the criteria of process hygiene for the $S$. aureus counts in cheeses prepared from raw milk were established $(\mathrm{n}=5, \mathrm{c}=2$, $\mathrm{m}=10^{4}$ and $\mathrm{M}=10^{5} \mathrm{CFU} \mathrm{g}^{-1}$; EU Regulation No. 1441/2007). Even if the standards for E. coli maximal density are not given by the $\mathrm{EU}$, the compliance of the HACCP, good manufacture and hygiene practice can ensure the product safety and low health risk.

The aim of the work was to analyse cheeses prepared from raw milk from two different milk vending machines in dependence to the season conditions and in relation to the microbiological safety and sensory quality. The purpose was to provide arguments for legitimate heat treatment of milk from milk vending machines prior to consumption by human even if the fermentation process will be carried out properly. 


\section{Materials and methods}

\section{Cheese preparation}

The milk samples were obtained according to the manual on vending machines and transported in sterile jars in cool boxes into the laboratory. Immediately after transport (within 30 minutes), the preparation began according to the procedure recommended for public (www.mliekomat.sk). Raw milk (2 L) was heated to $30^{\circ} \mathrm{C}$ and than coagulated for $30 \mathrm{~min}$ by adding $1 \mathrm{~mL}$ of commercial rennet (FROMASE 220, DSM, Heerlen, Holland, strength $220 \mathrm{IMCU} \mathrm{mL}^{-1}$ ). The curd was cut into cubes of $1 \mathrm{~cm}$ and heated to $45^{\circ} \mathrm{C}$. After that, the content was spilled through sterile cheesecloth, pressed by hand to exclude as much whey as possible. The cheeses were hung to drain at ambient temperature for $6 \mathrm{~h}$ and then placed to thermostat at $15{ }^{\circ} \mathrm{C}$ for 7 days. Four batches were made in summer and four in winter from two different vending machines (machine $\mathrm{A}$ and machine $\mathrm{B}$ ).

\section{Microbiological analyses}

$5 \mathrm{~g}$ curd of cheese sample was homogenized with $45 \mathrm{~mL}$ of sterile peptone saline solution in a BAGMIXER 400 (Interscience, Paris, France) for 1 min. In order to obtain growth curves, the actual numbers of different microbial groups in samples were determined at predefined time intervals by ten-fold dilution via plating on the following media (all from Merck, Darmstadt, Germany): S. aureus on Baird-Parker egg yolk tellurite agar incubated at $37{ }^{\circ} \mathrm{C}$ for $24 \mathrm{~h}$ (ISO STN 6888-1), total coliforms and E. coli on Chromocult agar incubated at $37^{\circ} \mathrm{C}$ for $24 \mathrm{~h}$ (ISO STN 4832), lactic acid bacteria on $\mathrm{M} 17$ agar incubated at $30^{\circ} \mathrm{C}$ for $48-72 \mathrm{~h}$ (ISO STN 4833 ) and on MRS agar under anaerobic conditions incubated at $37^{\circ} \mathrm{C}$ for $24 \mathrm{~h}$ (ISO STN 15124). At the same time the $\mathrm{pH}$ value of cheese samples was determined by direct insertion of a $\mathrm{pH}$ meter probe (WTW $720 \mathrm{pH}$ meter, Inolab, Weilheim, Germany).

\section{Fitting the growth curves and calculating the growth parameters}

The growth parameters (lag phase duration, growth rate and others) from each individual growth curve ( $\log \mathrm{CFU} \mathrm{g}^{-1}$ vs. time in $\mathrm{h}$ ) were calculated by using the mechanistic modelling technique of Baranyi and Roberts (1994) which is incorporated in the DMFit tools kindly provided by Dr. J. Baranyi (IFR Norwich, UK). The specific growth rates $\mu\left(\right.$ in $\left.^{-1}\right)$ were recalculated from the exponential phase growth rates ( $\mathrm{Gr}$ in $\log \mathrm{CFU}$ $\left.\mathrm{g}^{-1} \mathrm{~h}^{-1}\right)$ by $\mu=G r \cdot \ln 10$.

\section{Sensory analysis}

The panel of 10 evaluators assessed the smell, taste and appearance of cheeses by the use of $10 \mathrm{~cm}$ long undivided line segment. The results were evaluated by the t-test and F-test by using the Excel data tools, and compared at $95 \%$ level of significance.

\section{Results and discussion}

The average total microbial counts in raw milk used for cheese manufacture in summer and in winter were $3.910^{5} \mathrm{CFU} \mathrm{mL} \mathrm{mL}^{-1}$ and $5.310^{4} \mathrm{CFU} \mathrm{mL}^{-1}$, respectively. According to data presented in tables 1 and 2, lactic acid bacteria were the most common microbial groups in cheese samples. And as it was also assumed, the counts of all tested microorganisms were lower in winter milk. Since the results of microbial analysis of raw milks were described in our previous work (Valík et al., 2011), in this work we would like to deal with the results obtained during cheese preparation.

The average counts of microorganisms in young cheeses were higher about at least $0.5 \log$ than those found in milk used. According to Rodrígues et al. (1995) such an increase in counts in the curd due to physical retention of the microorganisms in the coagulum and due to the microbial growth during coagulation and whey drainage is a normal process in cheese making. This was also confirmed by the lower counts of microorganisms in whey (tab. 1 and 2) compared to counts in milk and in young cheese.

During the fermentation of cheeses at $15{ }^{\circ} \mathrm{C}$ the counts of all microbial groups increased, as it is shown on the characteristic growth curves (Fig. 1) from the one chosen cheese. The specific growth rates of LAB determined on MRS agar were almost twice higher in summer cheeses compared to winter cheeses $\left(\mu_{L A B, S}=0.303 \mathrm{~h}^{-1}, \mu_{L A B, w}=0.147 \mathrm{~h}^{-1}\right)$ and, similarly, the LAB determined on M17 agar multiplied faster in summer than in winter $\left(\mu_{L A B, S}=0.247 \mathrm{~h}^{-1}\right.$, $\left.\mu_{L A B, w}=0.168 \mathrm{~h}^{-1}\right)$. But the maximal counts were reached even after 2 or 3 days of fermentation, that was in comparison to our previous experiments later about 1 or 2 days (Medvedová et al., 2010). As a result of slow LAB's growth, the $\mathrm{pH}$ value diminution to $\mathrm{pH}=5.0$ occurred only after 2 or 3 days of fermentation in summer and in winter, respectively.

Due to the slow cheese acidification, the weak inhibition of $S$. aureus was noticed. Even if the initial $S$. aureus counts in milk can be assumed as meeting the hygienically requirements, in all cheeses the pathogen microorganism reached counts higher than $4 \mathrm{log}$, that is maximal accepted density of $S$. aureus required by the EU legislative 
No. 1441/2007. As we reported previously, the fast cheese acidification in the first $6 \mathrm{~h}$ of fermentation to the levels unacceptable for $S$. aureus is the most crucial way of pathogen growth and potential enterotoxins production elimination (LeMarc et al., 2009; Medved’ová et al., 2010). Similarly, also Öner et al. (2006), Menéndez et al. (2001) and Zárate et al. (1997) confirmed that $\mathrm{pH}$ value down to 5.0 is the consequential barrier for $S$. aureus multiplication to the counts higher than $6.0 \mathrm{log}$, that are necessary for the thermo-stable enterotoxins production. In comparison to cheeses prepared with active lactic acid starter cultures (Medved'ová et al., 2010), the growth of $S$. aureus was only about $1 \log$ counts, and the counts in stationary phase were lower than $4 \log$.

Neither the growth of E. coli nor the coliforms were influenced by the presence of naturally occurring

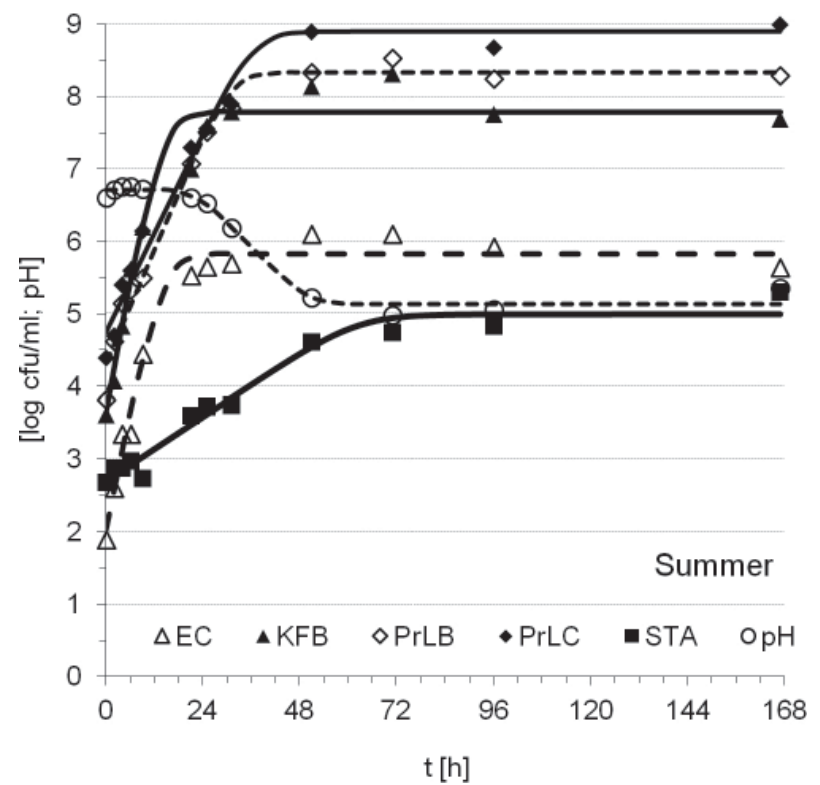

lactic acid bacteria in cow's milk. Since the counts of microorganisms were lower in winter, also the density of E. coli in young cheese was about $2 \mathrm{log}$ lower in winter compared to summer cheeses. It started to grow with the specific growth rate of $\mu_{E C, S}=0.588 \mathrm{~h}^{-1}$ or $\mu_{E C, w}=0.229 \mathrm{~h}^{-1}$ during the first $24 \mathrm{~h}$ of fermentation, thanks to that it reached counts about $3.5 \mathrm{log}$ higher in $24 \mathrm{~h}$ old cheeses. Similarly, the coliforms achieved counts higher about $3 \mathrm{log}$ than in young cheeses, after one day of fermentation. Moreover, also in this case, the specific growth rates of coliforms in summer cheeses were higher about $35 \%$ compared to the specific growth rates of coliforms in winter cheeses. The previous defined criteria $\left(10^{4} \mathrm{CFU} \mathrm{g}^{-1}\right)$ by the Slovak Food Codex for the E. coli counts in cheeses prepared from raw milk were exceeded in all prepared cheeses. Both growth of $S$. aureus and of E. coli can be satisfactorily inhib-

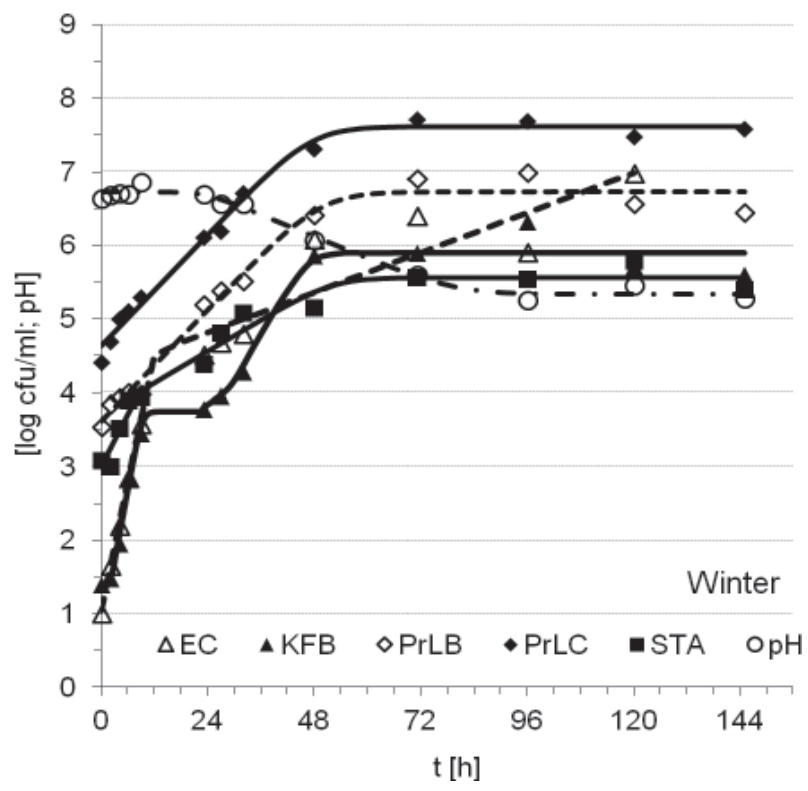

Fig. 1. Representative growth dynamic of microorganisms and $\mathrm{pH}$ value changes in cows' lump cheeses prepared in summer and in winter and stored at $15^{\circ} \mathrm{C}$. EC - Escherichia coli, KFB - coliform bacteria, PrLB - lactobacilli, PrLC - lactococci, STA - Staphylococcus aureus.

Tab. 1. Specific growth rates in exponential phase $(\mu)$ of microbial groups, their log counts and $\mathrm{pH}$ value changes during manufacture and fermentation of 4 cows' cheeses made in summer.

\begin{tabular}{lcccccc}
\hline & LAB $($ M17) & LAB $($ MRS) & S. aureus & coliforms & E. coli & pH \\
\hline milk & $3.80 \pm 0.36$ & $3.68 \pm 0.55$ & $2.32 \pm 0.29$ & - & - & - \\
whey & $3.58 \pm 0.61$ & $2.72 \pm 0.66$ & $1.66 \pm 0.63$ & $1.62 \pm 0.75$ & $1.12 \pm 0.66$ & - \\
cheese 0 h & $4.52 \pm 0.67$ & $3.63 \pm 0.55$ & $2.68 \pm 0.22$ & $3.17 \pm 0.57$ & $2.53 \pm 1.04$ & $6.62 \pm 0.01$ \\
cheese 24 h & $7.69 \pm 0.34$ & $7.26 \pm 0.26$ & $3.67 \pm 0.05$ & $7.01 \pm 0.64$ & $6.13 \pm 0.75$ & $6.58 \pm 0.09$ \\
cheese 48 h & $8.78 \pm 0.17$ & $8.25 \pm 0.12$ & $4.71 \pm 0.14$ & $7.77 \pm 0.39$ & $6.60 \pm 0.97$ & $5.37 \pm 0.20$ \\
cheese 72 h & $8.98 \pm 0.10$ & $8.58 \pm 0.21$ & $5.01 \pm 0.50$ & $7.85 \pm 0.70$ & $6.55 \pm 0.51$ & $5.16 \pm 0.12$ \\
cheese 96 h & $8.73 \pm 0.14$ & $8.30 \pm 0.30$ & $5.22 \pm 0.41$ & $7.61 \pm 0.45$ & $6.61 \pm 0.88$ & $5.09 \pm 0.12$ \\
\hline$\mu\left[\mathrm{h}^{-1}\right]$ & $0.247 \pm 0.050$ & $0.303 \pm 0.042$ & $0.081 \pm 0.020$ & $0.588 \pm 0.218$ & $0.671 \pm 0.091$ & $-0.066 \pm 0.031$ \\
\hline
\end{tabular}

LAB(M17) - lactic acid bacteria grown on M17 medium, LAB (MRS) - lactic acid bacteria grown on MRS medium. 
Tab. 2. Specific growth rates in exponential phase $(\mu)$ of microbial groups, their log counts and $\mathrm{pH}$ value changes during manufacture and fermentation of 4 cows' cheeses made in winter.

\begin{tabular}{lcccccc}
\hline & LAB $(\mathbf{M 1 7})$ & LAB $($ MRS) & S. aureus & coliforms & E. coli & pH \\
\hline milk & $3.05 \pm 0.35$ & $3.24 \pm 0.24$ & $2.06 \pm 0.50$ & - & - & - \\
whey & $3.51 \pm 0.07$ & $3.06 \pm 0.32$ & $1.66 \pm 0.60$ & $1.27 \pm 0.86$ & $0.97 \pm 1.20$ & - \\
cheese 0 h & $4.01 \pm 0.35$ & $3.66 \pm 0.14$ & $2.34 \pm 0.74$ & $1.75 \pm 1.36$ & $0.85 \pm 0.60$ & $6.61 \pm 0.05$ \\
cheese 24 h & $5.97 \pm 0.12$ & $5.55 \pm 0.31$ & $3.39 \pm 0.69$ & $4.92 \pm 1.01$ & $4.56 \pm 1.18$ & $6.68 \pm 0.14$ \\
cheese 48 h & $7.41 \pm 0.27$ & $6.90 \pm 0.80$ & $4.35 \pm 0.56$ & $6.39 \pm 0.63$ & $5.94 \pm 1.44$ & $6.08 \pm 0.26$ \\
cheese 72 h & $7.91 \pm 0.49$ & $7.41 \pm 0.91$ & $4.47 \pm 0.80$ & $6.80 \pm 0.82$ & $6.19 \pm 1.38$ & $5.58 \pm 0.22$ \\
cheese 96 h & $7.98 \pm 0.55$ & $7.68 \pm 1.05$ & $4.40 \pm 0.78$ & $7.02 \pm 0.54$ & $5.82 \pm 1.21$ & $5.31 \pm 0.08$ \\
\hline$\mu\left[\mathrm{h}^{-1}\right]$ & $0.168 \pm 0.027$ & $0.147 \pm 0.026$ & $0.105 \pm 0.031$ & $0.229 \pm 0.043$ & $0.438 \pm 0.238$ & $-0.029 \pm 0.008$ \\
\hline
\end{tabular}

LAB (M17) - lactic acid bacteria grown on M17 medium, LAB (MRS) - lactic acid bacteria grown on MRS medium.

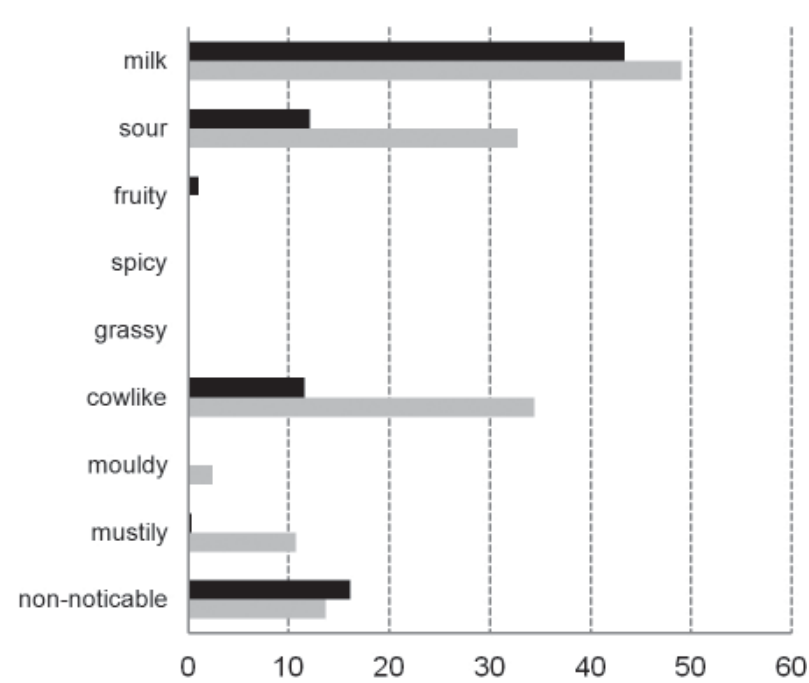

A: "winter $\Perp$ summer

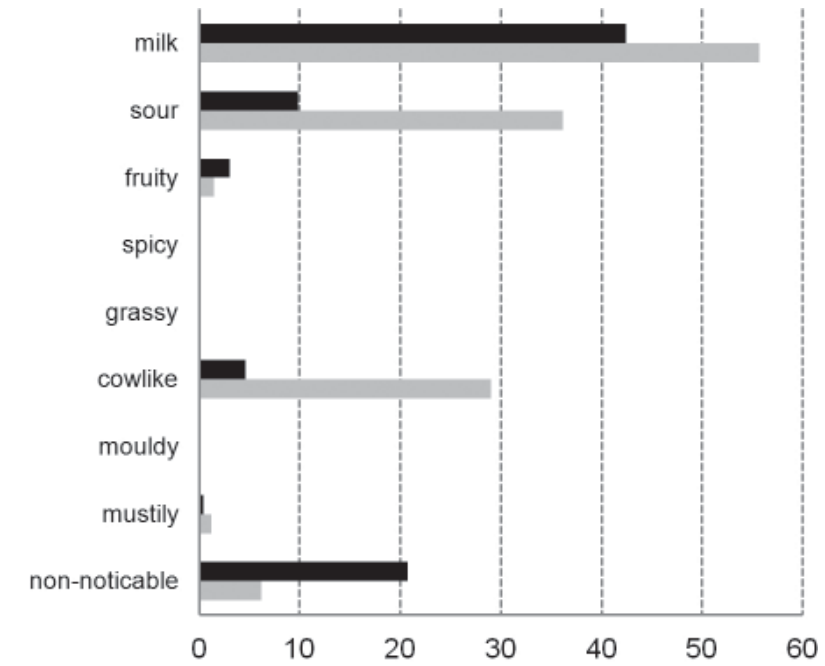

B: winter "summer

Fig. 2. Comparison of sensory evaluation of smell of cheeses prepared in summer and winter from raw milk from vending machines A (2a) and B (2b).

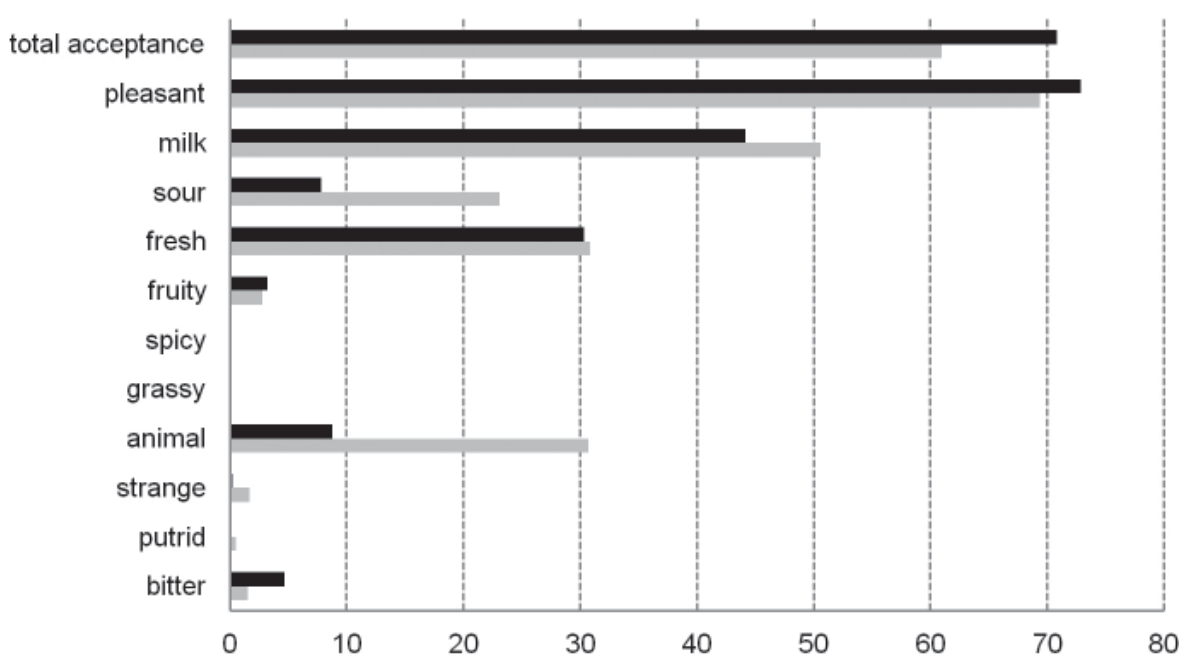

A: —winter $\|$ summer

Fig. 3a. Comparison of sensory evaluation of taste of cheeses prepared in summer and winter from raw milk from vending machines A. 


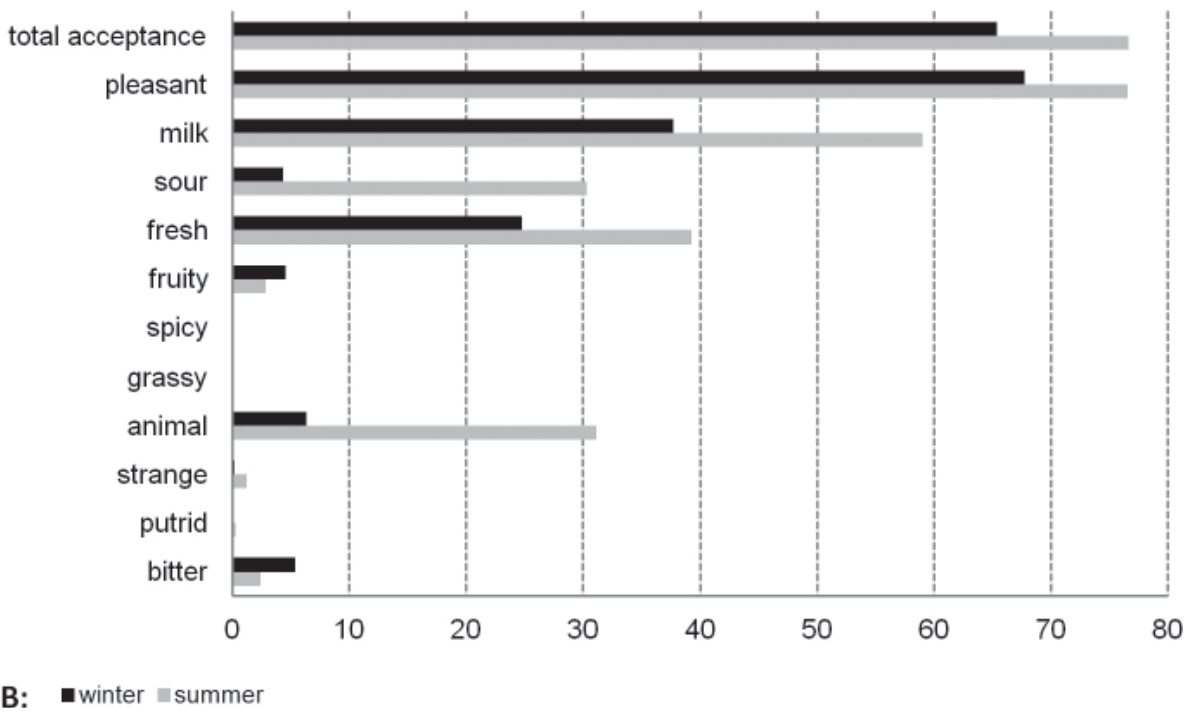

Fig. 3b. Comparison of sensory evaluation of taste of cheeses prepared in summer and winter from raw milk from vending machines $\mathrm{B}$.

ited by the addition of lactic acid bacteria to the levels that do not represent any potential health threat and are under the legislative acceptations (Medvedová et al., 2010, Liptáková et al., 2008).

According to the sensory analysis (data not shown), the significant $(\mathrm{P}>0.05)$ differences between summer and winter cheeses were in colour intensity. Summer cheeses had whiter colour than winter cheeses and were softer. In summer, the smell of cheeses was more intensive and had more dairysour odour (Fig. 2a and 2b). The taste of summer cheeses was more dairy, more animal, sourer and generally more accepted by the evaluators (Fig. 3a and $3 \mathrm{~b}$ ). However, in cheeses prepared from milk vending machine $\mathrm{A}$, the total acceptance was higher in cheeses prepared from winter milk.

\section{Conclusion}

The results of microbiological analysis confirmed that raw milk from milk vending machines is not suitable for direct consumption by population. Even more, it is also not appropriate for the manufacture of lump cheese without preceding milk heat treatment or adding of lactic acid bacteria starter cultures. According to the procedure for household preparation of cheeses accessible to public, the temperature of $15^{\circ} \mathrm{C}$ was recommended. This temperature led to the slower lactic acid bacteria growth, organic acid production and subsequently to the inappropriate $\mathrm{pH}$ value decrease. Relatively high initial counts of micro-organisms in raw material and also the slow $\mathrm{pH}$ value decrease led to the unacceptable densities of micro-organisms non-desirable from the hygienic and health reasons. Only the meeting of the good manufacture practice and conditions during milking and processing of raw milk can ensure the product of desired qualities. On the top of that, the addition of starter culture can support the growth of natural lactic acid bacteria present in raw milk. Their inhibitory potential, involving not only acidification, can be used actively in safe cheese preparation and can also improve the sensory level of the product. The sensory analysis confirmed the generally known fact that the raw material of less quality diminishes the microbiological safety of the product.

\section{Acknowledgement}

This work was supported by the contract APVV no. 059010 and STU grant: "Effect of environmental factors on the growth of Staphylococcus aureus and Escherichia coli".

\section{References}

Asperger H, Zangerl P (2003). In: Roginski H, Fuquay JW, Fox PF (Ed) Encyclopedia of Dairy Sciences. Vol. 4 (pp 2563-2569). Academic Press, San Diego.

Baranyi J, Roberts TA (1994) International Journal of Food Microbiology 23: 277-294.

Burdová O, Lauková A (2001) Mliekarstvo 32: 22-24.

Commission Regulation (EC) No. 1441/2007 (2007): Amending Regulation (EC) No. 2073/2005 on microbiological criteria for foodstuffs. 18p.

Delbes C, Alomar J, Chougui N, Martin JF, Montel MCH (2006) Journal of Food Protection 69: 2161-2167.

Donnelly CW (2004). In Fox P, McSweeney P, Cogan T, Guinee T (Ed) Cheese: Chemistry, Physics and Microbiology, Vol. 1 (pp 541-559) Academic Press, Hardbound.

LeMarc Y, Valík L, Medved’ová A (2009) International Journal of Food Microbiology 129: 306-311.

Lim SK, Lee HS, Nam HM, Cho YS, Kim JM, Song SW, Park YH, Jung SC (2007) International Journal of Food Microbiology 115: 283-286. 
Liptáková D, Valík L, Medved’ová A, Hudecová A (2008) Slovak Journal of Animal Science 41: 91-97.

Lindqvist R, Sylvén S, Vågsholm I (2002) International Journal of Food Microbiology 78: 155-170.

Little CL, Rhoades JR, Sagoo SK, Harris J, Greenwood M, Mithani V, Grant K, McLauchlin J (2008) Food Microbiology 25: 304-312.

Medved’ová A, Valík L', Liptáková D, Hudecová A (2010) Potravinárstvo 4: 50-54.

Menéndez S, Godínez R, Centeno JA, Rodríguez-Otero JL (2001) Food Microbiology 18: 151-158.

Öner Z, Karahan AG, Aloglu H (2006) LWT 39: 449-454.

Rivas L, Fegan N, Dykes GA (2007) International Journal of Food Microbiology 115: 89-94.

Rodrígues JM, Martínez MI, Horn N, Dodd HM (2003) International Journal of Food Microbiology 80: $101-116$.

EN ISO 4832 (1997) Microbiology: General principles for the enumeration of coliforms bacteria. International Organization for Standardization, Geneva, 8p.

EN ISO 4833 (1997) Microbiology: General principles for the enumeration of total microorganisms count. Geneva: International Organization for Standardization, 9p.

EN ISO 6888-1 (1999) Microbiology of food and animal feeding stuffs. Horizontal method for the enumeration of coagulase-positive staphylococci (Staphylococcus aureus and other species). Part 1: Technique using Baird-Parker agar medium. International Organization for Standardization, Geneva, 22 pp.

EN ISO 15124 (2002) Mikrobiológia potravín a krmív: Horizontálna metóda stanovenia mezofilných baktérií mliečneho kysnutia. Metóda počítania kolónií kultivovaných pri $30{ }^{\circ} \mathrm{C}$. Slovenský ústav technickej normalizácie, Bratislava, $12 \mathrm{~s}$.

Valík L', Görner F, Sonneveld K, Polka P (2004). In Štětina J, Čurda L (Ed) Celostátní přehlídky sýrů, 2004: Výsledky přehlídek a sborník přednášek semináře Mléko a sýry 2004. (pp 85-87). Česká společnost chemická, Praha.

Valík L, Medved’ová A, Bírošová L, Liptáková D, Ondruš L, Šnelcer J (2011) Potravinárstvo 3: 38-43.

Zárate V, Belda F, Pérez C, Cardell E (1997) International Dairy Journal 7: 635-641. 